\title{
BIODEGRADABLE WASTE MANAGEMENT BY ANAEROBIC DIGESTION: A COMPARISON BETWEEN POLICY APPROACHES AND REGULATION IN ITALY AND ISRAEL
}

\author{
Francesco Di Maria *,1, Ofira Ayalon ${ }^{2}$ and Shira Daskal ${ }^{2}$ \\ 1 LAR5 Laboratory, Dipartimento di Ingegneria, University of Perugia, via G. Duranti 93, 06125, Italy \\ ${ }^{2}$ The Department of Natural Resources and Environmental Management, University of Haifa, 3498838, Israel
}

Article Info:
Received:
22 August 2018
Revised:
24 June 2018
Accepted:
5 September 2018
Available online:
30 September 2018
Keywords:
Anaerobic digestion (AD)
Bio-waste
Digestate
Policy
Regulation
Legislation

Article Info:

Received:

Revised:

Legislation

\begin{abstract}
Biodegradable waste is a significant component of municipal solid waste (MSW); anaerobic digestion allows the recycling of this waste. This paper presents a comparison between definitions, management, and usage of digestate/sludge and sewage from the anaerobic digestion (AD) of biodegradable waste in Italy and Israel in light of the legislation in both countries. Italian legislation is focused on three main components of the whole management/ recycling chain of bio-waste: the source of the waste, the characteristics of the digestate, the environmental matrix (i.e., soil and water) affected by the use of the digestate. Some relevant differences are currently present in the legislation concerning bio-waste and the sewage sludge management. In particular, both EU and Italian legislation lack specific "end-of-waste criteria" regarding the digestate from the AD of bio-waste. The legislation in Israel, on the other hand, is more focused on the application of the digestate and sewage from AD plants on soil rather than the source of the bio-waste. The focus on the end product (waste, water or sludge) is due to scarcity of water as well as soil sensitivity for agriculture use. The comparison indicates profound differences between the two countries, revealing inter alia advantages and disadvantages.
\end{abstract}

\section{INTRODUCTION}

In a dynamic, complex, and globalised world, an integrated and multidisciplinary approach is needed in order to analyse and solve complex problems. Such an approach is highly reflected in a joint international research (Brissaud, 2008). Scientific cooperation between Italy and Israel goes back to the early days of the Israeli state, inter alia as both are Mediterranean countries with similar agricultural crops and raw food materials (Tous \& Ferguson, 1996). The scientific cooperation between the two countries is not limited to the natural sciences and Mediterranean studies, but extends to history, art, the classics, archaeology, and numerous other scholarly domains (Pagliaro, 2017). The current study compares policy approaches and regulation for biodegradable waste management by anaerobic digestion in Italy and Israel in light of the great challenges both countries are facing in the management of biodegradable waste and its by-products.

Thanks to a strong and reliable political, legal, and economic supporting scheme (EC, 2001), the EU has become a leader in production of renewable energy, with a total production of about $70 \mathrm{M}$ ton oil equivalents. Anaerobic diges- tion (AD), with more than 17,500 facilities in the member states of the EU, and with total installed power of about $9,000 \mathrm{MW}$ (EBA, 2016) contributes approximately $7.5 \%$ of the total renewable energy in Europe (EEA, 2016). Most diffused feedstocks for $A D$ are represented by energy crops (ECR) (mainly maize), contributing to the production of more than $50 \%$ of the whole of the biogas generated (EC, $2017 a$ ), yet representing a cost increase from about $0.08 € /$ $\mathrm{kWh}$ to about $0.15 € / \mathrm{kWh}$ (Schievano et al., 2015). This last aspect represents a serious threat to the viability of these facilities considering that many of them are now approaching the end of the period of economic subsidies.

A possible and widely studied solution (Pognani et al., 2009; Schievano et al., 2009) is the partial or total replacement of ECR with other substrates among which bio-waste is of particular interest. AD as treatment for bio-waste recycling is also considered a suitable technology for the implementation of a circular economy in this sector (EC, 2017b). Furthermore, since the bio-waste represents more than $30 \%$ of the whole of EU municipal waste, in order to achieve the overall recycling goals imposed by EU legislation (WFD, 2008) (i.e., 50\% within 2020) recycling of bio-waste is crucial. Economic aspects limit the exploitation of $A D$ in this 
sector to only about $10 \%$ of the EU28 bio-waste potential (ISPRA, 2017). For this reason, the replacement of ECR with bio-waste could provide an important opportunity for using the under capacity of existing ECR facilities the viability of existing ECR facilities and the further implementation of EU policy in the bio-waste sector at reduced investment costs. One should bear in mind that the management of the digestate is of particular concern in light of the absence of uniform EU end-of-waste (EoW) criteria. In fact, according to EU legislation (WFD, 2008), digestate from biomasses and ECRs are still considered biomasses, whereas digestate from waste is still considered waste. This legal distinction has affected successive management schemes. The most frequently adopted solution is preliminary solid/liquid separation with successive post-composting of the solid fraction to achieve the standard quality imposed by the organic fertilizer regulation. Since about $90 \%$ of $A D$ used for ECR is of the wet type, more than $70 \%$ of the solid/liquid separation is still represented by the liquid fraction of the digestate. In some cases, its use on land can be authorized by legal entities in accordance with the $\mathrm{R} 10$ recovery operation "land treatment resulting in benefit to agriculture or ecological improvement" (Annex II, WFD, 2008) but in other cases its further processing in wastewater treatment plants (WWTP) could be requested in order to achieve standard water quality before discharge and/or reuse. In this case, even if the outlet water from WWTP is reused, the bio-waste cannot be considered recycled. WWTP is another important EU and Italian sector in which $A D$ is widely exploited even if mainly for environmental considerations (i.e., the biological stabilized sludge before disposal/use) (Di Maria et al., 2016; Di Maria and Micale, 2017). Currently in the EU area there are some 36,000 WWTPs equipped with an $A D$ section for sludge, representing another relevant source of digestate/sludge to be managed. Sludge can also be recovered by the R10 operation.

This approach arises from the Italian and EU legislation that imposes two main goals on the waste sector (CD, 1986; CD, 1991a,b: EC, 2015; WFD, 2008). The first goal is to manage waste without affecting the environment, including human health. The second goal is to make the best possible use of waste materials that can replace raw materials. In the specific case of digestate and sludge, the goal is to replace mineral fertilizers with the ones obtained from those processes. Due to great differences in climatic conditions and soil characteristics across Italy and EU, more specific details related to the quality of soils and specific features for use of these materials on land are usually outlined in local legislation.

Israel is characterised by an arid and semi-arid climate and its water resources are very limited. Water is one of the most significant environmental issues and a major concern in Israel, where the arable land area is approximately $4,200 \mathrm{~km} 2$ and the irrigated land area is about 1,866 km2 (Inbar, 2007). The water sector in Israel is subject to the Water Authority (WA), which has overall responsibility for it (Water Law, 1959) and legislation is created at the national level. The Water Authority also supervises the establishment of wastewater treatment facilities by the local authorities, mainly city associations or water corporations that are also required to maintain these systems (Sewage Law, 1962). The Water Law declares that all water resources are public property subject to the control of the state, thus there are no private water rights or resources in Israel and water may only be used by permit holders. As water consumption exceeds the natural rate of replenishment, while the intensity of freshwater use is extremely high by OECD standards (OECD, 2011).

Financial instruments for reducing consumption, such as a $40 \%$ increase in domestic water prices (introduced in January 2010) and financial penalties for pollution were also implemented in order to enhance overall water cycle management. Established in 1937, Mekorot, the National Water Company, supplies $70 \%$ of total water consumption. Water supplied to agriculture is mainly provided by Mekorot directly or by Agricultural Water Associations. Mekorot treats some $40 \%$ of the country's wastewater. The Ministry of Environmental Protection (MoEP) is responsible for protecting water quality and preventing water pollution. In the eastern Mediterranean region, irrigation with water of marginal quality has a long history, with Israel being the most prominent pioneer in advanced treated wastewater use policy and technology (Schacht et al., 2016).

This paper aims to compare and discuss the differences in legislation and practices related to biodegradable waste treatment and its liquid and solid digestate recycling between EU (and hence the Italian) and Israeli legislation.

\subsection{List of Acronyms}

$\begin{array}{ll}\text { AD } & \text { Anaerobic Digestion } \\ \text { CFU } & \text { Colony Forming Units } \\ \text { COLL } & \text { Collection } \\ \text { ECR } & \text { Energy Crops } \\ \text { EoW } & \text { End of Waste } \\ \text { EU } & \text { European Union } \\ \text { KWh } & \text { Kilo Watt hour } \\ \text { MBT } & \text { Mechanical and Biological Treatment } \\ \text { MCM } & \text { Million Cubic Meters } \\ \text { MoEP } & \text { Ministry of Environmental Protection } \\ \text { Mol } & \text { Ministry of Interior } \\ \text { MPN } & \text { Most Probable Number } \\ \text { MSW } & \text { Municipal Solid Waste } \\ \text { MSWM } & \text { Municipal Solid Waste Management } \\ \text { OECD } & \text { Organization for Economic Co-operation and } \\ & \text { Development } \\ \text { PFU } & \text { Plaque Forming Units } \\ \text { STD } & \text { Standards } \\ \text { TS } & \text { Total Solids } \\ \text { WA } & \text { Water Authority } \\ \text { WR } & \text { Water Regulations } \\ \text { WWTP } & \text { Wastewater Treatment Plants }\end{array}$

\section{METHODOLOGY}

The scientific approach in this study is based on a joint international study for conducting a comparative analysis of the policy approaches and regulation in Italy and in Israel. Such a comparison is expected to point to advantages and disadvantages of the management systems in both 
countries and thus contribute to the enhancement of these systems.

The comparison implemented in this study required the collection, classification, and processing of various data, including documentation such as laws, regulations, government decisions, and qualitative data. The data was retrieved from literature and from official documents of legal entities charged with waste planning and monitoring. Furthermore, data from previous works of the authors were considered. The legislation in both countries was reviewed and processed into a visual scheme of the technical and legal recycling pathway of bio-waste via AD in both countries, providing an accessible way to understanding the various "decision junctions" along the pathway as a tool to support conclusions drawn from the comparative analysis.

The following definitions will be adopted in the study: liquid digestate, the fraction of digestate characterized by a Total Solids TS $\leq 10 \% \mathrm{w} / \mathrm{w}$ and sludge, the digestate characterized by a TS $\geq 15 \%$. It is important to note that in the EU, as in Italy, the term "sludge" is usually used to refer to the sludge generated by the sludge treatment lines (primary and activated) of wastewater treatment plants; the above term "sludge" applies to Israel as well.

\section{RESULTS}

\subsection{Italian legislation and scenario}

\subsubsection{Waste management legislation}

The reference legislation for waste management in Italy arises from the adoption of the latest EU directive, the Waste Framework Directive 2008/98/EC (WFD, 2008). This directive imposes some relevant goals to be achieved by the member states at given times. In particular, by 2020 not less than $50 \%$ of waste, such as paper, plastics, cardboard, metals, and glass, is required to be prepared for reuse and/ or recycled. The recycling of bio-waste, as defined by the EC Environment, by recovery operation R3 "Recycling/ reclamation of organic substances which are not used as solvents (including composting and other biological transformation processes" (Annex II, WFD, 2008) is intended to contribute to the achievement of this goal.

Alternatively, bio-waste can be considered recycled after $A D$ if the digestate is effectively used on land. In this case, due to the absence of EU EoW criteria, the authorization of this operation is subject to the standard qualities imposed by the Council Directive 86/728/EEC (CD, 1986) on the agronomic use of sludge from WWTP classified as the $\mathrm{R} 10$ recovery operation. This imposes limits regarding the concentration of heavy metals and other pollutants, including pathogens, for the sludge but also limits on the content of heavy metals for the soils on which the sludge is spread (Table 1). Another relevant legal aspect to be considered in use on land is Council Directive 91/767/EEC (CD, 1991a) concerning the protection of water against pollution caused by nitrates from agricultural sources. This Directive limits the amount of nitrogen in soils to $170 \mathrm{kgN} / \mathrm{ha} / \mathrm{year}$ for vulnerable areas, and $340 \mathrm{kgN} / \mathrm{ha} /$ year for non-vulnerable areas. In any case, separated collection of bio-waste is a compulsory requirement for its recycling (main water
TABLE 1: Chemical and physical features for use of sludge from WWTP on land (D.Lgs., 1999).

\begin{tabular}{|c|c|}
\hline Parameter & Value \\
\hline \multicolumn{2}{|l|}{ For sludge from WWTP } \\
\hline $\mathrm{Cd}(\mathrm{mg} / \mathrm{kg} \mathrm{TS})$ & 20 \\
\hline $\mathrm{Hg}(\mathrm{mg} / \mathrm{kg} \mathrm{TS})$ & 10 \\
\hline $\mathrm{Ni}(\mathrm{mg} / \mathrm{kg} \mathrm{TS})$ & 300 \\
\hline $\mathrm{Pb}(\mathrm{mg} / \mathrm{kg} \mathrm{TS})$ & 750 \\
\hline $\mathrm{Cu}(\mathrm{mg} / \mathrm{kg} \mathrm{TS})$ & 1,000 \\
\hline Zn (mg/kg TS) & 2,500 \\
\hline TOC (\%TS) (min) & 20 \\
\hline Total P (\%TS) (min) & 0.4 \\
\hline Total N (\%TS) (min) & 1.5 \\
\hline Salmonella MPN/g TS (max.) & $10^{3}$ \\
\hline \multicolumn{2}{|l|}{ For soil } \\
\hline $\mathrm{N}$ for vulnerable areas (kg/ha/year) & 170 \\
\hline $\mathrm{N}$ for non-vulnerable areas (kg/ha/year) & 340 \\
\hline $\mathrm{Cd}(\mathrm{mg} / \mathrm{kg} \mathrm{TS})$ & 1.5 \\
\hline $\mathrm{Hg}(\mathrm{mg} / \mathrm{kg} \mathrm{TS})$ & 1 \\
\hline $\mathrm{Ni}(\mathrm{mg} / \mathrm{kg} \mathrm{TS})$ & 75 \\
\hline $\mathrm{Pb}(\mathrm{mg} / \mathrm{kg} \mathrm{TS})$ & 100 \\
\hline $\mathrm{Cu}(\mathrm{mg} / \mathrm{kg} \mathrm{TS})$ & 100 \\
\hline $\mathrm{Zn}(\mathrm{mg} / \mathrm{kg} \mathrm{TS})$ & 300 \\
\hline
\end{tabular}

and wastewater legislations are listed in Table 2).

\subsubsection{Wastewater management legislation}

In cases where the digestate from bio-waste cannot be used on land, it usually undergoes a liquid/solid separation. According to current legislation and standard quality, the solid fraction can be composted for the production of organic fertilizer, whereas the liquid fraction is moved to WWTPS with appropriate permits. In these facilities, the liquid digestate is usually co-treated with domestic wastewater, and the goal of the treatment is to reintroduce the water into the system in compliance with the water standard quality imposed by the current legislation. Specifically, there are two main water standard references (Table 3): one for discharge in surface water (e.g., lakes, rivers), the other for reuse.

In the latter case, the legislation refers to three possible reuses: agricultural, industrial, and domestic, with the exclusion of drinking and hygienic use. Currently, at the EU level, water reuse is strongly promoted (CD, 1991b), but no target has been defined yet. Italy currently reuses about $9 \%$ of its wastewater based on quality of water discharged by WWTPS, while the potential is estimated to be $60 \%$ (EC, 2015). Even if the purified water is reused, this cannot be considered recycling of bio-waste since the goal of WWTP is to remove N and $P$, which represent the real focus of recycling for the EU legislation (i.e., R3 and R10 operations).

\subsubsection{Anaerobic digestion of bio-waste}

In the EU28, the bio-waste production potential is of about 90Mtonnes. Currently, approximately 40 Mtonnes 
TABLE 2: Main water and wastewater legislations in Italy.

\begin{tabular}{|c|c|c|}
\hline Year & Legislation & Purpose \\
\hline 1896 & Local regulations on hygiene of soil and house & $\begin{array}{l}\text { To establish the main regulation for surface water cleaning, drinking water supply and delivery, } \\
\text { wastewater disposal }\end{array}$ \\
\hline 1904 & Legal regulation for hydraulic works & To establish the state as responsible for the protection of public water and related works \\
\hline 1933 & $\begin{array}{l}\text { Legal regulation for water and hydraulic power } \\
\text { plants }\end{array}$ & $\begin{array}{l}\text { To identify the users in terms of small and large public water withdrawal, define the regulations } \\
\text { for the search for and extraction and use of ground water, roles for the transmission and distri- } \\
\text { bution of electrical energy }\end{array}$ \\
\hline 1934 & Sanitary legislation & $\begin{array}{l}\text { To outline the hygienic conditions for water outflow and impose treatment for wastewater } \\
\text { before discharge in water bodies }\end{array}$ \\
\hline 1963 & Master plan for aqueduct & To plan the water supply and delivery system \\
\hline 1976 & $\begin{array}{l}\text { Legal regulation for protection of water from } \\
\text { pollution }\end{array}$ & $\begin{array}{l}\text { To represent the first legal framework regarding wastewater management, collection, and } \\
\text { treatment }\end{array}$ \\
\hline 1898 & $\begin{array}{l}\text { Legal regulations for the reorganization and } \\
\text { protection of the soil }\end{array}$ & To establish soil protection, water reclamation, management of water bodies \\
\hline 1994 & Regulation on water resources & To rationalise the national water supply system \\
\hline 1999 & Regulation on water protection from pollution & $\begin{array}{l}\text { To define the general principles for prevention and reduction of the pollution, sustainable use } \\
\text { and preservation of natural self-capacity of purification of water bodies }\end{array}$ \\
\hline 2003 & Regulation on water and wastewater reuse & To impose possible reuse of the wastewater after purification process and the standard quality \\
\hline
\end{tabular}

TABLE 3: Main water quality standards for discharge in surface water and reuse in Italy (D.Lgs., 2006; D.M. 2003).

\begin{tabular}{|c|c|c|c|}
\hline Parameter & Units & $\begin{array}{l}\text { Surface Water } \\
\quad(\max )\end{array}$ & $\begin{array}{l}\text { Reuse } \\
\text { (max) }\end{array}$ \\
\hline $\mathrm{pH}$ & $\mathrm{mg} / \mathrm{l}$ & $5.5-9.5$ & $6-9.5$ \\
\hline $\mathrm{SAR}^{\mathrm{a}}$ & $\mathrm{mmol} / \mathrm{l}$ & - & 10 \\
\hline Solids & $\mathrm{mg} / \mathrm{l}$ & None & None \\
\hline BOD5 & $\mathrm{mg} / \mathrm{l}$ & $25-40$ & 20 \\
\hline COD & $\mathrm{mg} / \mathrm{l}$ & $125-160$ & 100 \\
\hline Total P & $\mathrm{mg} / \mathrm{l}$ & $2-1$ & 2 \\
\hline Total N & $\mathrm{mg} / \mathrm{l}$ & $15-10$ & 15 \\
\hline $\mathrm{N}-\mathrm{Ammonia}\left(\right.$ as $\mathrm{NH}_{4}$ ) & $\mathrm{mg} / \mathrm{l}$ & 15 & 2 \\
\hline Conductivity (mS) & $\mathrm{mS} / \mathrm{cm}$ & - & 3,000 \\
\hline Al & $\mathrm{mg} / \mathrm{l}$ & 1 & 1 \\
\hline As & $\mathrm{mg} / \mathrm{l}$ & 0.5 & 0.02 \\
\hline $\mathrm{Ba}$ & $\mathrm{mg} / \mathrm{l}$ & 20 & 10 \\
\hline $\mathrm{Be}$ & $\mathrm{mg} / \mathrm{l}$ & - & 0.1 \\
\hline Bo & $\mathrm{mg} / \mathrm{l}$ & 2.0 & 1.0 \\
\hline $\mathrm{Cd}$ & $\mathrm{mg} / \mathrm{l}$ & 0.02 & 0.005 \\
\hline Co & $\mathrm{mg} / \mathrm{l}$ & - & 0.05 \\
\hline Total $\mathrm{Cr}$ & $\mathrm{mg} / \mathrm{l}$ & 2.0 & 0.1 \\
\hline $\mathrm{Cr}+6$ & $\mathrm{mg} / \mathrm{l}$ & 0.20 & 0.005 \\
\hline $\mathrm{Fe}$ & $\mathrm{mg} / \mathrm{l}$ & 2 & 2 \\
\hline $\mathrm{Mn}$ & $\mathrm{mg} / \mathrm{l}$ & 2 & 0.2 \\
\hline $\mathrm{Hg}$ & $\mathrm{mg} / \mathrm{l}$ & 0.005 & 0.001 \\
\hline $\mathrm{Ni}$ & $\mathrm{mg} / \mathrm{l}$ & 2 & 0.2 \\
\hline $\mathrm{Pb}$ & $\mathrm{mg} / \mathrm{l}$ & 0.2 & 0.1 \\
\hline $\mathrm{Cu}$ & $\mathrm{mg} / \mathrm{l}$ & 0.1 & 1 \\
\hline $\mathrm{Se}$ & $\mathrm{mg} / \mathrm{l}$ & 0.03 & 0.01 \\
\hline Sn & $\mathrm{mg} / \mathrm{l}$ & 10 & 3 \\
\hline TI & $\mathrm{mg} / \mathrm{l}$ & - & 0.001 \\
\hline V & $\mathrm{mg} / \mathrm{l}$ & - & 0.1 \\
\hline $\mathrm{Zn}$ & $\mathrm{mg} / \mathrm{l}$ & 0.5 & 0.5 \\
\hline Total CN & $\mathrm{mg} / \mathrm{l}$ & - & 0.05 \\
\hline
\end{tabular}

Legend: a=Sodium Adsorption Ratio for soils are recycled mainly by composting (3,500 facilities) and only 8 Mtones are processed or co-processed by AD (about 245 facilities). Italy has a bio-waste production potential of approximately 9 Mtonnes. Of this amount, as of 2016, 3.4 Mtonnes are recycled by composting in 274 plants, about 2 Mtonnes are recycled by integrated AD and post-composting facilities in 31 plants, and about 0.25 Mtonnes are processed by $A D$ in 21 plants. $A$ large part of the liquid digestate generated after solid/liquid separation is currently processed by WWTP. A minor amount is currently used on land in accordance with the R10 operation.

\subsection{Israeli legislation and scenario}

\subsubsection{Waste management legislation}

Until the early 1990 s, $97 \%$ of the MSW produced in Israel was landfilled in hundreds of unregulated sites that were used and operated by local authorities. Following the closure of hundreds of unregulated dumps during the 1990s, the MoEP declared a "recycling revolution" that included a comprehensive program for transitioning from landfilling to turning MSW into a resource via recycling. The initial goal set by the MoPE in 1998 was to increase MSW recycling and recovery rates to $25 \%$ by 2007 . Beginning in 2006 , further steps were taken, including the imposition of a landfill levy and the establishment of a financial support program for local authorities to promote separation at source (Daskal et al., 2018). To date, separation at source of biowaste is not mandatory and most bio-waste is landfilled without any treatment. In particular, $A D$ is not mandatory, implementation of this treatment method is relatively low, and the definitions of this process are vague as there are no clear classifications regarding recycling vs. recovery. In light of the above, sludge management in Israel is mainly associated with WWTP.

\subsubsection{Water and wastewater management legislation}

Leapfrogging in the treatment and reuse of wastewater in Israel occurred when the state took the lead on this issue, set standards, and financed projects, making Israeli 
industry a world leader in wastewater treatment and disposal. There are numerous laws and regulations that relate to water and wastewater in Israel. Table 4 presents the most central of these.

\subsubsection{Sludge management legislation}

The Water Regulations (WR, 2004) are aimed to prevent the pollution of water resources and the creation of environmental nuisances as a result of uncontrolled disposal of sludge originating in municipal sewage. The regulations classify sludge according to various definitions based on the level of treatment and the characteristics of the material obtained. Table 5 presents classification of sludge and various materials according to the Water Regulations (2004).

TABLE 4: Main water and wastewater legislation in Israel.

\begin{tabular}{|c|c|c|}
\hline Year & Legislation & Purpose \\
\hline 1957 & $\begin{array}{l}\text { The Drainage and Flood Prevention Law, } \\
1957\end{array}$ & $\begin{array}{l}\text { The } 11 \text { drainage authorities are primarily responsible for drainage of agricultural runoff, including } \\
\text { through channelisation of rivers. }\end{array}$ \\
\hline 1959 & The Water Law, 1959 & Establishes the framework for the control and protection of Israel's water sources. \\
\hline 1962 & The Local Authorities Sewage Law, 1962 & $\begin{array}{l}\text { Prescribes the rights and duties of local authorities in the design, construction, and maintenance of } \\
\text { sewage systems. }\end{array}$ \\
\hline 1971 & The Water Law Amendment, 1971 & $\begin{array}{l}\text { Outlines prohibitions against direct or indirect water pollution, regardless of the state of the water } \\
\text { beforehand. }\end{array}$ \\
\hline 1981 & $\begin{array}{l}\text { Discharge of Industrial Sewage into the } \\
\text { Sewage System, Model Local Authorities } \\
\text { Bylaw, } 1981\end{array}$ & $\begin{array}{l}\text { Sets recommendations to local authorities on the treatment of industrial sewage and its disposal } \\
\text { into the sewage system. }\end{array}$ \\
\hline 1988 & $\begin{array}{l}\text { Streams and Springs Authorities Order } \\
\text { (Yarkon River Authority), } 1988\end{array}$ & $\begin{array}{l}\text { Establishes the Yarkon River Authority, which includes: prevention and abatement of stream pollu- } \\
\text { tion, planning and implementation of rehabilitation schemes, and transformation of the area into a } \\
\text { recreational site. }\end{array}$ \\
\hline 1991 & $\begin{array}{l}\text { Prevention of Water Pollution - Rinsing } \\
\text { of Containers for Spraying, Regulations, } \\
1991\end{array}$ & $\begin{array}{l}\text { Prohibits aerial spraying of biological and/or chemical substances for agricultural purposes near } \\
\text { a water source, including Lake Kinneret, the open sections of the National Water Carrier, the Upper } \\
\text { Jordan River and its tributaries, and other sources of drinking water. }\end{array}$ \\
\hline 1992 & $\begin{array}{l}\text { Prevention of Water Pollution - Cesspits } \\
\text { and Septic Tanks, Regulations, } 1992\end{array}$ & $\begin{array}{l}\text { Establishes prohibitions and restrictions regarding the construction of new cesspools and septic } \\
\text { tanks and on existing ones, including timetables for the gradual elimination of cesspools under } \\
\text { certain conditions. }\end{array}$ \\
\hline 1994 & $\begin{array}{l}\text { Prevention of Water Pollution - Reduc- } \\
\text { tion of Salt Use in the Regeneration } \\
\text { Process, Regulations, } 1994\end{array}$ & $\begin{array}{l}\text { Requires industries to undertake a number of technical steps to bring about salt reduction in the re- } \\
\text { generation of ion exchange in order to reduce the quantity of salt used in the water-softening process } \\
\text { and the consequent emission of brines into the municipal water system. }\end{array}$ \\
\hline 1994 & $\begin{array}{l}\text { Streams and Springs Authorities Order } \\
\text { (Kishon River Authority), } 1994\end{array}$ & $\begin{array}{l}\text { Establishes the Kishon River Authority, whose functions include: prevention and abatement of stream } \\
\text { pollution, planning and implementation of rehabilitation schemes, and transformation of the area into } \\
\text { a recreational site. }\end{array}$ \\
\hline 1997 & $\begin{array}{l}\text { Prevention of Water Pollution - Gasoline } \\
\text { Stations, Regulations, } 1997\end{array}$ & $\begin{array}{l}\text { Requires specific conditions for the establishment and operation of gas stations, including instal- } \\
\text { lation of fuel-water separators, use of impermeable construction materials, special measures and } \\
\text { equipment to prevent leakage and oil pollution, measures for protection against corrosion, and } \\
\text { monitoring equipment and procedures. }\end{array}$ \\
\hline 1997 & $\begin{array}{l}\text { Prevention of Water Pollution - Evapo- } \\
\text { ration and Storage Ponds, Regulations, } \\
1997\end{array}$ & $\begin{array}{l}\text { Aims to prevent water pollution from evaporation and collection (storage) ponds, on the one hand, } \\
\text { and restricting their use, on the other. }\end{array}$ \\
\hline 1998 & $\begin{array}{l}\text { Prevention of Water Pollution - Prohi- } \\
\text { bition on Discharge of Brines to Water } \\
\text { Sources, Regulations, } 1998\end{array}$ & $\begin{array}{l}\text { Prohibits the discharge of brines from ion-exchange renewal, from food, tanning and textile indus- } \\
\text { tries, and from hospitals to water sources and the municipal sewage system. }\end{array}$ \\
\hline 1998 & $\begin{array}{l}\text { Prevention of Water Pollution - Sewage } \\
\text { Disposal from Vessels, Regulations, } 1998\end{array}$ & $\begin{array}{l}\text { Prohibits the discharge of sewage from a vessel to a water source, requires commercial vessels to } \\
\text { install adequate sewage collection facilities, and calls for the establishment of adequate reception } \\
\text { facilities on shore. }\end{array}$ \\
\hline 2000 & $\begin{array}{l}\text { Prevention of Water Pollution - Metals } \\
\text { and Other Pollutants, Regulations, } 2000\end{array}$ & $\begin{array}{l}\text { Aims to protect water sources from heavy metals and other pollutants by limiting the volume of } \\
\text { wastewater discharged from pollution sources and reducing the concentration of pollutants in it. }\end{array}$ \\
\hline 2001 & $\begin{array}{l}\text { The Water and Sewage Association Law, } \\
2001\end{array}$ & $\begin{array}{l}\text { Increases efficiency of municipal water supply and sanitation services via public service entities } \\
\text { called 'Water and Sewerage Corporations'. }\end{array}$ \\
\hline 2003 & $\begin{array}{l}\text { Prevention of Water Pollution - pH Values } \\
\text { of Industrial Sewage, Regulations, } 2003\end{array}$ & $\begin{array}{l}\text { Sets } \mathrm{pH} \text { values of industrial sewage in order to protect the environment and prevent the pollution of } \\
\text { water sources from the corrosive impacts of industrial sewage. }\end{array}$ \\
\hline 2003 & $\begin{array}{l}\text { Salt Concentrations in Industrial Sewage, } \\
\text { Regulations, } 2003\end{array}$ & Sets threshold values for salt concentrations in industrial sewage. \\
\hline 2004 & $\begin{array}{l}\text { Prevention of Water Pollution - Usage of } \\
\text { Sludge, Regulations, } 2004\end{array}$ & $\begin{array}{l}\text { Aims to prevent water source pollution and environmental degradation as a result of improper dis- } \\
\text { posal of sludge originating in municipal sewage treatment plants. }\end{array}$ \\
\hline 2006 & $\begin{array}{l}\text { Prevention of Water Pollution - Fuel } \\
\text { Pipelines, Regulations, } 2006\end{array}$ & $\begin{array}{l}\text { Reduces potential risks from fuel transport pipelines, thereby preventing environmental degradation } \\
\text { and pollution of water sources. }\end{array}$ \\
\hline 2010 & $\begin{array}{l}\text { Effluent Quality Standards and Rules for } \\
\text { Sewage Treatment, Regulations, } 2010\end{array}$ & $\begin{array}{l}\text { Aims to protect public health, prevent pollution of water sources from sewage and effluents, } \\
\text { facilitate the recovery of effluents as a water source, protect the environment, including ecological } \\
\text { systems and biological diversity, soil, and agricultural crops. }\end{array}$ \\
\hline 2011 & $\begin{array}{l}\text { Prevention of Water Pollution - Waste- } \\
\text { water Conveyance System, Regulations, } \\
2011\end{array}$ & $\begin{array}{l}\text { Aims to prevent leaks from wastewater conveyance systems in order to protect water sources, eco- } \\
\text { systems, biodiversity, and other natural resources and prevent environmental hazards, inter alia, by } \\
\text { imposing charges and issuing directives in accordance with the provisions of these regulations. }\end{array}$ \\
\hline
\end{tabular}


TABLE 5: Classification of sludge and various materials according to the Water Regulations (2004).

\begin{tabular}{|c|c|}
\hline Definition & Description \\
\hline "Sludge" & $\begin{array}{l}\text { A by-product of a sewage treatment process in a sewage treatment plant (except in a process in which crude filtering and separation } \\
\text { of sand and oils is carried out) }\end{array}$ \\
\hline $\begin{array}{l}\text { "Stabilized } \\
\text { Sludge" }\end{array}$ & Sludge that has undergone treatment according to a plan approved by the Ministry of Environmental Protection \\
\hline “Class A Sludge” & $\begin{array}{l}\text { Stabilized sludge that satisfies the following requirements: } \\
\text { (1) The geometric mean of the density of faecal coliform type bacteria, determined from at least seven samples of the sludge, is } \\
\text { less than } 1000 \text { MPN per one gram of dry material or the arithmetical mean of salmonella bacteria, determined from at least seven } \\
\text { samples of the sludge, is less than } 3 \text { MPN per four grams of dry material } \\
\text { (2) The arithmetical average of enteric viruses determined from at least seven samples of the sludge is less than one PFU per four } \\
\text { grams of dry material } \\
\text { (3) The arithmetical average of density of viable helminth ova determined from at least seven samples of the sludge is less than } 1 \\
\text { to four grams of dry material, provided that the sampling was conducted in accordance with the method prescribed in Book } 3 \text { and } \\
\text { explained in Book } 4\end{array}$ \\
\hline "Class B Sludge" & $\begin{array}{l}\text { Stabilized sludge in which the geometric average of the density of faecal coliform type bacteria determined according to at least } \\
\text { seven samples is less than two million MPN or CFU per one gram of dry material }\end{array}$ \\
\hline “Dry Material” & $\begin{array}{l}\text { Material obtained after drying of sludge at a temperature of } 105 \text { degrees centigrade by the method prescribed in Book and explained } \\
\text { in Book } 4\end{array}$ \\
\hline "Volatile material" & $\begin{array}{l}\text { Material found in sludge that evaporates after heating of the dry material at a temperature of } 550 \text { degrees centigrade, in the presence } \\
\text { of oxygen, according to the method prescribed in Book } 1 \text { and explained in Book } 4\end{array}$ \\
\hline "Total nitrogen" & The arithmetical amount of concentrations of Kjeldahl nitrogen, $\mathrm{N}$ - nitrite and $\mathrm{N}$ - nitrate according to the methods described in Book 1 \\
\hline
\end{tabular}

In 2016, 118,019 tons of sludge were disposed of from 63 WWTPs. Thirty-three percent of this amount was discharged into the Mediterranean Sea and $67 \%$ was removed to land destinations as presented in Figure 1 (MoEP, 2017). In 2016, most of the sludge that was removed to land-based destinations (which did not flow into the sea) was used for agricultural purposes, after it passed additional sanitary processing and turned into fertilizer/soil enhancement for unlimited use ("Class A Sludge" in accordance with the regulations - see Table 5). The trend of sludge disposal from WWTPs between 2002 and 2016 is presented in Figure 2.

\subsubsection{Effluent management legislation}

As water scarcity is a major concern, Israel has introduced ambitious water policies and pioneered cutting-edge water-efficient technologies, including drip irrigation, brackish and seawater desalination, and soil aquifer treatment for reuse of treated wastewater.

In Israel, the local authorities are responsible for the construction and operation of wastewater treatment plants. Israel's wastewater treatment plants use intensive (mechanical/biological) and extensive treatment processes. From a total of 500 million cubic meters (MCM) of sewage produced in Israel in 2008 , about $70 \%$ of the effluents were reclaimed. Local authorities are responsible for the treatment of municipal sewage. In recent years new or upgraded intensive treatment plants have been set up in municipalities throughout the country. The ultimate objective is to treat $100 \%$ of Israel's wastewater in order to bring it to a level that enables unrestricted irrigation in accordance with soil sensitivity and without risk to soil and water sources (MoEP, 2014). The effluent quality and wastewater treatment regulations issued by the Ministry of Environmental Protection (MoEP) and the Ministry of Health in 2010 include 36 parameters that may not be exceeded in effluent whose use in irrigation will be unrestricted or that will be discharged to rivers. Sewage treatment effluent is the most readily available water source and provides a partial solution to the water scarcity problem. Table 6 presents

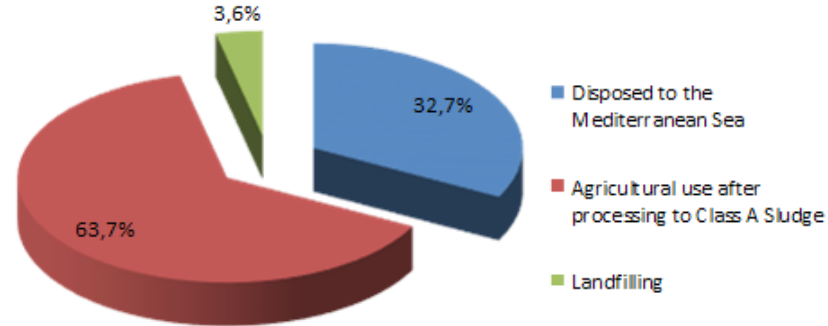

FIGURE 1: A diagram of sludge disposal from WWTPs for 2016 (MoEP, 2017).

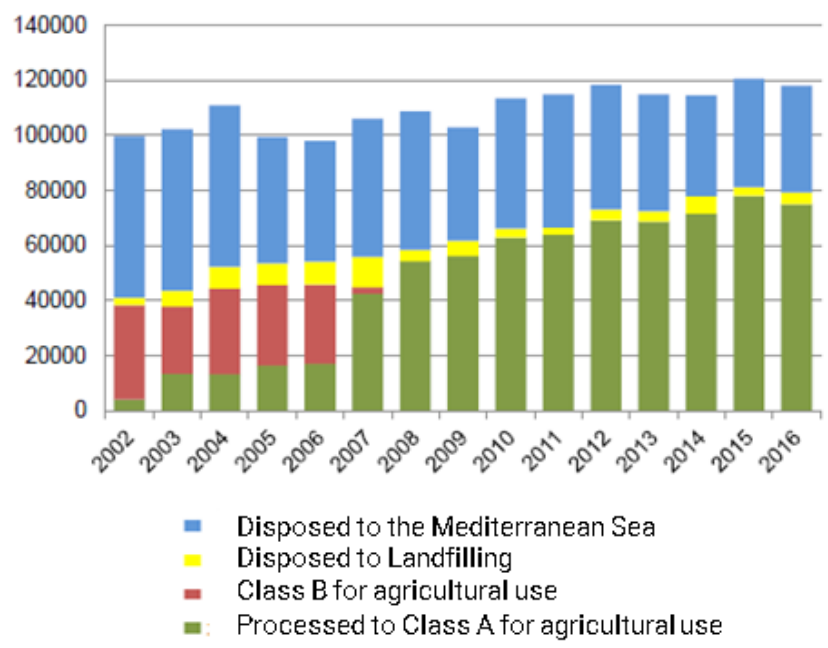

FIGURE 2: A diagram of sludge disposal from WWTPs between 2002 and 2016 (MoEP, 2017).

the restrictions on the use of effluents.

\section{DISCUSSION}

This comparative survey highlights some profound differences between Italy and Israel in the approaches and in legislation concerning the recycling of bio-waste and the management of sludge and liquid fractions generated from 
TABLE 6: Israeli standards for effluent (average levels) $(\mathrm{MoH}, 2010)$.

\begin{tabular}{|c|c|c|c|}
\hline Parameter & Units & $\begin{array}{l}\text { Unrestricted } \\
\text { Irrigation }\end{array}$ & Rivers \\
\hline Electric conductivity & $\mathrm{dS} / \mathrm{m}$ & 1.4 & $n / a$ \\
\hline BOD & $\mathrm{mg} / \mathrm{l}$ & 10 & 10 \\
\hline TSS & $\mathrm{mg} / \mathrm{l}$ & 10 & 10 \\
\hline COD & $\mathrm{mg} / \mathrm{l}$ & 100 & 70 \\
\hline $\mathrm{N}-\mathrm{NH} 4$ & $\mathrm{mg} / \mathrm{l}$ & 20 & 1.5 \\
\hline Total nitrogen & $\mathrm{mg} / \mathrm{l}$ & 25 & 10 \\
\hline Total phosphorus & $\mathrm{mg} / \mathrm{l}$ & 5 & 1.0 \\
\hline Chloride & $\mathrm{mg} / \mathrm{l}$ & 250 & 400 \\
\hline Fluoride & $\mathrm{mg} / \mathrm{l}$ & 2 & $\mathrm{n} / \mathrm{a}$ \\
\hline Sodium & $\mathrm{mg} / \mathrm{l}$ & 150 & 200 \\
\hline Faecal coliforms & Unit per $100 \mathrm{ml}$ & 10 & 200 \\
\hline Dissolved oxygen & $\mathrm{mg} / \mathrm{l}$ & $>0.5$ & $>3$ \\
\hline $\mathrm{pH}$ & $\mathrm{mg} / \mathrm{l}$ & $6.5-8.5$ & $7.0-8.5$ \\
\hline Residual chlorine & $\mathrm{mg} / \mathrm{l}$ & 1 & 0.05 \\
\hline Anionic detergent & $\mathrm{mg} / \mathrm{l}$ & 2 & 0.5 \\
\hline Mineral oil & $\mathrm{mg} / \mathrm{l}$ & $\mathrm{n} / \mathrm{a}$ & 1 \\
\hline SAR & $(\mathrm{mmol} / \mathrm{l}) 0.5$ & 5 & $\mathrm{n} / \mathrm{a}$ \\
\hline Boron & $\mathrm{mg} / \mathrm{l}$ & 0.4 & $n / a$ \\
\hline Arsenic & $\mathrm{mg} / \mathrm{l}$ & 0.1 & 0.1 \\
\hline Mercury & $\mathrm{mg} / \mathrm{l}$ & 0.002 & 0.0005 \\
\hline Chromium & $\mathrm{mg} / \mathrm{l}$ & 0.1 & 0.05 \\
\hline Nickel & $\mathrm{mg} / \mathrm{l}$ & 0.2 & 0.05 \\
\hline Selenium & $\mathrm{mg} / \mathrm{l}$ & 0.02 & $\mathrm{n} / \mathrm{a}$ \\
\hline Lead & $\mathrm{mg} / \mathrm{l}$ & 0.1 & 0.008 \\
\hline Cadmium & $\mathrm{mg} / \mathrm{l}$ & 0.01 & 0.005 \\
\hline Zinc & $\mathrm{mg} / \mathrm{l}$ & 2 & 0.2 \\
\hline Iron & $\mathrm{mg} / \mathrm{l}$ & 2 & $\mathrm{n} / \mathrm{a}$ \\
\hline Copper & $\mathrm{mg} / \mathrm{l}$ & 0.2 & 0.02 \\
\hline Manganese & $\mathrm{mg} / \mathrm{l}$ & 0.2 & $\mathrm{n} / \mathrm{a}$ \\
\hline Aluminium & $\mathrm{mg} / \mathrm{l}$ & 5 & $\mathrm{n} / \mathrm{a}$ \\
\hline Molybdenum & $\mathrm{mg} / \mathrm{l}$ & 0.01 & $n / a$ \\
\hline Vanadium & $\mathrm{mg} / \mathrm{l}$ & 0.1 & $\mathrm{n} / \mathrm{a}$ \\
\hline Beryllium & $\mathrm{mg} / \mathrm{l}$ & 0.1 & $\mathrm{n} / \mathrm{a}$ \\
\hline Cobalt & $\mathrm{mg} / \mathrm{l}$ & 0.05 & $\mathrm{n} / \mathrm{a}$ \\
\hline Lithium & $\mathrm{mg} / \mathrm{l}$ & 2.5 & $\mathrm{n} / \mathrm{a}$ \\
\hline Cyanide & $\mathrm{mg} / \mathrm{l}$ & 0.1 & 0.005 \\
\hline
\end{tabular}

$\mathrm{AD}$. Figures $3 \mathrm{a}$ and $3 \mathrm{~b}$ schematically present the Italian and Israeli procedure for bio-waste recycling via AD, respectively.

This comparison suggests three main differences between the EU legislation (Italy) and the Israeli legislation:

1) Source of the bio-waste, which has to be collected separately (for Italy and EU);

2) Quality of the digestate in terms of physical, chemical, and biological features;

3) Quality of the soils receiving the digestate, mainly in terms of heavy metals content.

In Italy, if one of the last two steps are not verified, the liquid has to be processed in a WWTP, resulting in a failure of bio-waste recycling (Figure 3a). This approach arises from two main factors: the implementation of the waste management hierarchy and the absence of EoW criteria for the digestate. According to EU legislation, the goal of the hierarchy is to make the best possible use of the waste materials for replacing and/or avoiding the consumption of raw materials. Pursuing this goal in the bio-waste sector means effective use on land of its organic nutrients content, e.g. N, K, P, for replacing mineral ones avoiding the consumption of mineral resources. On the other hand, there are currently no defined criteria specifying when the status of the bio-waste changes from waste to product (i.e., EoW criteria). This means that the use on land of digestate is not really forbidden, but it is necessary to activate an alternative legal procedure for assessing whether or not this activity can be performed. The legal pathway for doing this is stated in article 6 of the WFD 2008/98/EC, which enumerates the general mandatory criteria for the end-of-waste status: (a) the substance or object is commonly used for specific purposes; (b) a market or demand exists for such a substance or object; (c) the substance or object fulfils the technical requirements for the specific purposes and meets the existing legislation and standards applicable to products; and (d) the use of the substance or object will not lead to overall adverse environmental or human health impacts. The absence of a uniform EU legal support leads local and member state legal authorities to adopt procedure from similar legislation that in the specific case are usually represented by the current one concerning the agronomic use of sludge from WWTPs (Figure 3a). Of course, the chemical, physical, and biological features of the WWTP sludge are significantly different from those of the digestate from bio-waste. One main reason for concern is the risk of pollutant compounds, such as heavy metals, that can be quite high in sludge (Table 1). The reason for these concerns arises from the impossibility of having stringent control over the quality of the wastewater collected by the WWTP. In fact, sewage grids are usually mixed systems that collect domestic, commercial, and industrial sewage that, depending on different context, can significantly affect the quality of the sludge. Furthermore, sewage grids also collect rainwater from public roads and parking areas, and thus bring to the WWTP large amounts of pollutant compounds.

If, on the one hand, the EU and Italian legislation is strongly oriented toward the implementation of the waste management hierarchy, on the other hand it shows some weaknesses regarding the implementation of an efficient management of water resources. In the current EU legislation, which imposes an efficient use of water resources, unlike the waste management sector, no reuse/recycling targets were defined. In addition, in this case the lack of legal and political framework limits the achievement of high performances in this sector.

Yet, as Figure 3b shows, in Israel the approach is different. The national goal is the reduction of landfilling via recycling and thus, a landfill levy has been imposed since 2007. $A D$ in this case is considered a suitable technology for the recovery of bio-waste via the production of a soil amend- 


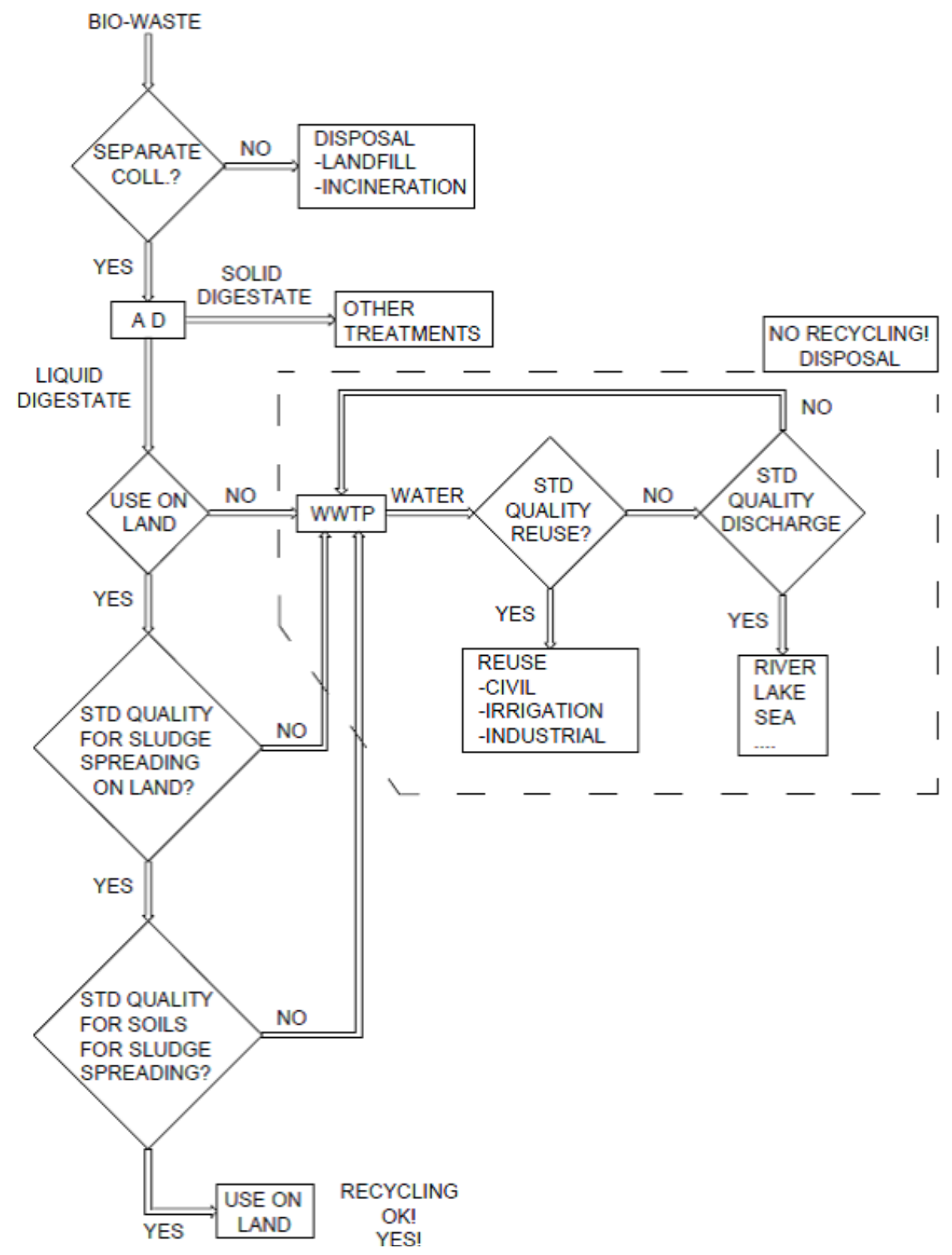

FIGURE 3a: Scheme of the technical and legal recycling pathway of bio-waste via AD in Italy.

ment and/or fertilizer. However, Israeli legislation is not focused on the source of the material, as demonstrated by the absence of mandatory rules on the source separation of bio-waste. Moreover, $A D$ is not specifically indicated by national policy as a suggested technology and its application is left to the choice of local authorities and municipalities. AD of bio-waste is thus an optional recycling method, performed mainly to reduce landfilling and increase recycling, based on the availability of adequate treatment facilities. Additionally, in Israel, unlike in Italy, bio-waste can be landfilled without any pre-treatment and there are no EoW criteria. Concerning the other two aspects related to quality of digestate/sludge and the soils that receive them, some other differences and similarities exist. In fact, both in Italy and Israel there are policies for assessing the quality of the digestate/sludge, with some differences.

The use of solid digestate (sludge) and liquid digestate (effluent) in Israel are well regulated, since there is concern regarding the possible effects of the use of these products on soil and water quality. On the other hand, Israeli legislation concerning sludge (i.e., the solid part) is more oriented toward pathogen content (see Table 5) and less focused on other potential pollutant risks, such as those caused by nitrogen. Italian and EU legislation also interact with water protection legislation where limits on the concentration of different nitrogen and other compounds (e.g., P) are also carefully addressed. Finally different approaches to the quality of receiving soils can be also detected (Tables 1,5).

Concerning the standard quality of water generated by WWTP of liquid digestate effluents (Tables 3,6 ), it is possible to note that, in general, Israeli standard quality is more stringent for discharge in rivers than for reuse. In contrast, the Italian and EU approach imposes more stringent limits for reused water in particular with regard to the main 


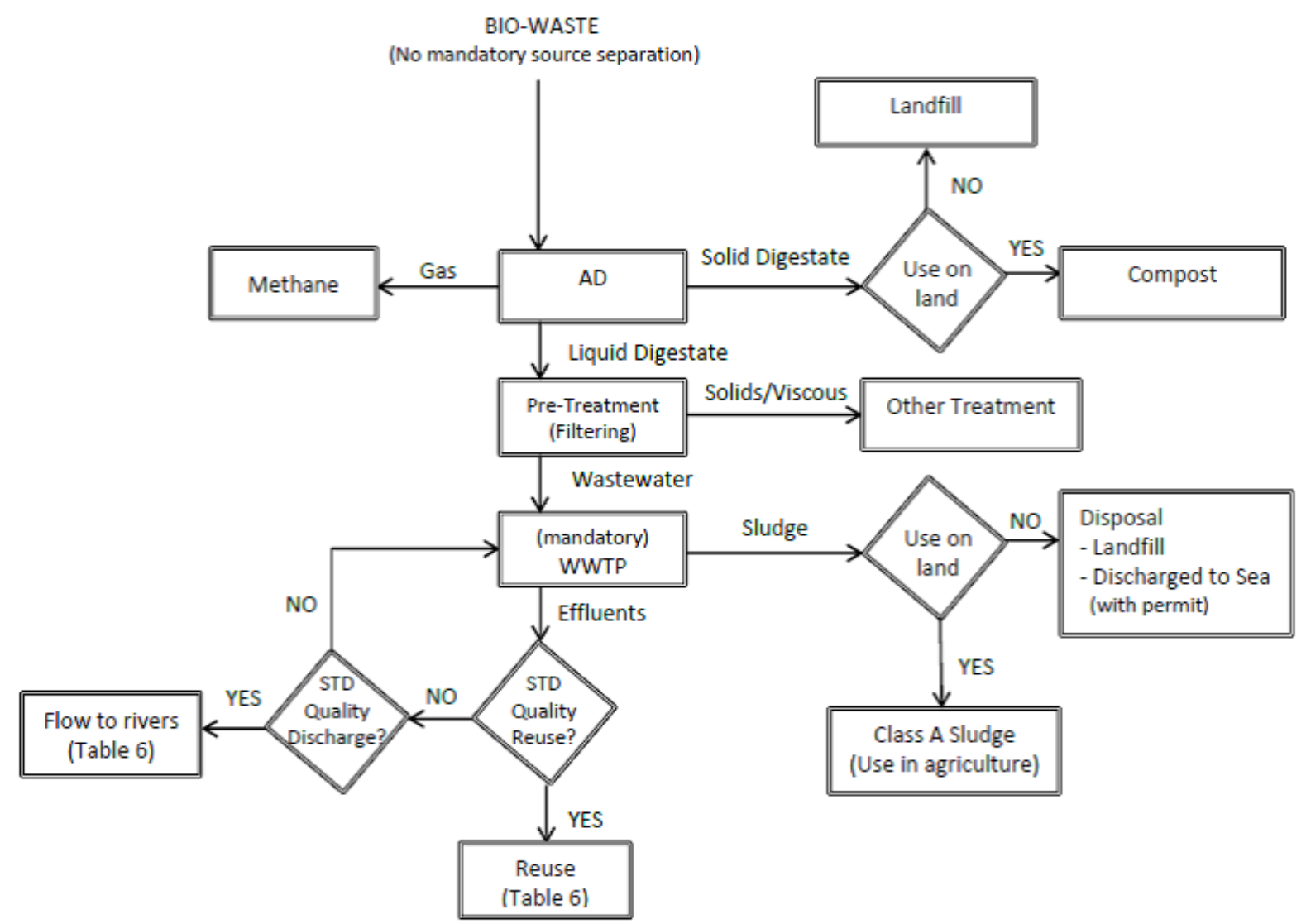

FIGURE 3b: Scheme of the technical and legal recycling pathway of bio-waste via AD in Israel.

parameters and COD, $\mathrm{N}$ and $\mathrm{P}$. This difference highlights the priority Israeli legislation gives to the reuse of water, as opposed to Italy and EU where currently this priority is stated, but not fully addressed.

\section{CONCLUSIONS}

The comparison presented in this paper points out some profound differences between regulation in Italy and Israel and raises some substantive issues:

1. The main differences that emerge from this study are the following:

I. Bio-waste definitions are different - the EU regulation addresses the source of the bio-waste, which dictates the product's destination, and thus in Italy the source of the bio-waste is the decisive factor that dictates its usage and destination. In Israel, on the other hand, the regulation relates to the receiving media of the products (soil/ agriculture use/rivers).

II. In order to recycle bio-waste, separation at source is mandatory in Italy, as the EU is concerned about contamination and possible health hazards of the recycled materials (e.g., compost and reclaimed water) whilst in Israel separation may be implemented at the end point based on technologies such as MBT.

III. The Italian legislation includes EoW criteria that apply inter alia to bio-waste only regarding its solid part, whereas in Israel such criteria are not yet anchored in legislation.
IV. Even if largely promoted by EU legislation, full implementation of $A D$ of bio-waste in Italy, as in the UE, suffers from the absence of uniform EoW for the digestate.

2. In order to "close the loop" of bio-waste via bio-waste recycling according to the EU legislation, separate collection must be of a very high quality. This requirement might be an obstacle in achieving the EU recycling goals, so further research should be implemented in order to determine whether the EU's strict legislation, which requires source separation, is indeed a must, or whether separation in an advanced sorting facility (MBT) is sufficient for further treatment in an AD facility.

3. The differences that arise from the comparison in this paper emphasize the crucial role of regulation and legislation. We conclude that adequate legal support is crucial for achieving sustainable systems.

4. Elaborating this comparison and further analysing the regulation and management systems of both countries may make it possible to enhance the wastewater cycle in a way that will contribute to the advancement of sustainable wastewater treatment systems in both countries, taking a step forward towards a circular economy.

\section{REFERENCES}

Brissaud, F. (2008). Criteria for water recycling and reuse in the Mediterranean countries. Desalination, 218(1-3), 24-33.

CD. (1986). Council Directive 86/278/EEC of 12 June 1986 on the protection of the environment, and in particular of the soil, when sewage sludge is used in agriculture. Official Journal L 181, 04/07/1986 P. $0006-0012$. 
CD. (1991a). Council Directive 91/676/EEC of 12 December 1991 concerning the protection of waters against pollution caused by nitrates from agricultural sources. Official Journal L 375 , 31/12/1991 P. $0001-0008$.

CD. (1991b). Council Directive 91/272/CEE of 21 May 1991 concerning urban waste water treatment. Official Journal L 135, 30/05/1991 P. 0040-0052.

Daskal, S. Ayalon, O. Shechter, M. (2018). The State of Municipal Solid Waste Management in Israel. Waste Management \& Research. In Press.

Di Maria, F., Micale, C., Contini, S. (2016). Energetic and environmental sustainability of the co-digestion of sludge with bio-waste in a life cycle perspective. Applied Energy 171; 67-76.

Di Maria, F., Micale, C. (2017). Energetic potential of the co-digestion of sludge with bio-waste in existing wastewater treatment plant digesters: A case study of an Italian province. Energy 136; 110-116.

D.Lgs. (1999). Decreto Legislativo 11 maggio 1999, n. 152. "Testo aggiornato del decreto legislativo 11 maggio 1999, n. 152, recante: "Disposizioni sulla tutela delle acque dall'inquinamento e recepimento della direttiva 91/271/CEE concernente il trattamento delle acque reflue urbane e della direttiva 91/676/CEE relative alla protezione delle acque dall'inquinamento provocato dai nitrati provenienti da fonti agricole", a seguito delle disposizioni correttive ed integrative di cui al decreto legislativo 18 agosto 2000, n. 258". Gazzetta Ufficiale n. 246, 20 Ottobre 2000. S.O. n.172 (in Italian)

D.Lgs. (2006). Decreto legislativo 3 aprile 2006, n. 152. Norme in materia ambientale Gazzetta Ufficiale. n. 88 del 14 aprile 2006. (in Italian)

D.M. (2003). DECRETO MINISTERIALE 12 giugno 2003, n. 185 «Regolamento recante norme tecniche per il riutilizzo delle acque reflue in attuazione dell'articolo 26, comma 2, del D.Lgs. 11 maggio 1999, n. 152». Gazetta Ufficiale 23 luglio 2003, S.O. n. 169. (in Italian)

EBA. (2016). EBA launches 6th edition of the Statistical Report of the European Biogas Association. Available at: http://european-biogas.eu/2016/12/21/eba-launches-6th-edition-of-the-statistical-report-of-the-european-biogas-association/ (accessed 22.8.18).

EC. (2001). DIRECTIVE 2001/77/EC OF THE EUROPEAN PARLIAMENT AND OF THE COUNCIL of 27 September 2001 on the promotion of electricity produced from renewable energy sources in the interna electricity market. Official Journal of the European Communities, 27.10.2001.

EC. (2015). Optimising water reuse in the EU - Final report Part I. ISBN 978-92-79-46835-3 doi: 10.2779/603205.

EC. (2017a). Optimal use of biogas from waste streams An assessment of the potential of biogas from digestion in the EU beyond 2020. Available at: https://ec.europa.eu/energy/sites/ener/files/ documents/ce_delft_3g84_biogas_beyond_2020_final_report.pdf (accessed 22.8.18).

EC. (2017b). Communication from the commission to the European Parliament, the council, the European economic and social committee and the committee of the regions. The role of waste-to-energy in the circular economy. $\operatorname{COM(2017)~} 34$ final, 26.1.2017. Available at: http://ec.europa.eu/environment/waste/waste-to-energy. pdf (accessed 22.8.18).
EEA. (2016). Renewable energy in Europe. Recent growth and knock-on effects. EEA report 4/2016. ISBN 978-92-9213-727-4

Inbar, Y. (2007). New standards for treated wastewater reuse in Israel. In Wastewater reuse-Risk assessment, decision-making and environmental security (pp. 291-296). Springer, Dordrecht.

ISPRA. (2017). Rapporto Rifiuti Urbani. Edizione 20176. ISPRA, Rapporti 272/2017. ISBN 978-88-448-0852-5.

MoEP. (2014).Wastewater. Available at: http://www.sviva.gov.il/ English/env_topics/Wastewater/Pages/default.aspx (accessed 22.8.18)

MoEP. (2017) Sewage disposal of municipal wastewater treatment plants (in Hebrew). Available at: http://www.sviva.gov.il/subjectsEnv/Wastewater/MunicipalWastewater/TreatmentPlants/ Pages/default.aspx (accessed 22.8.18)

$\mathrm{MoH}$.(2010).PublicHealthRegulations(Qualitystandardsforeffluentsand rules for sewage purification) (in Hebrew) Available at: https://www. health.gov.il/LegislationLibrary/Briut01.pdf (accessed 22.8.18)

OECD (2011). OECD Environmental Performance Reviews: Israel 2011. Available at: http://www.oecd-ilibrary.org/environment/oecd-environmental-performance-reviews-israel-2011_9789264117563-en (accessed 22.8.18)

Pagliaro, M. (2017). Scientific cooperation between Italy and Israel: A perspective looking to the future. J. Sci. Human. Arts, 4(2).

Pognani M, D'Imporzano G, Scaglia B, Adani F. (2009). Substitution energy crops with organic fraction of municipal solid waste for biogas production at farm level: A full-scale plant study. Process biochemistry 44,817-821.

Schievano A, D'Imporzano G, Adani F. (2009). Substituting energy crops with organic wastes and agro-industrial residues for biogas production. Journal of Environmental Management. 90,2537-2541.

Schievano A, D'Imporzano G, Orzi V, Colombo G, Maggiore T, Adani F. (2015). Biogas from dedicated energy crops in Northern Italy: electric energy generation costs. GCB Bioenergy 7,899-908.

Schacht, K., Chen, Y., Tarchitzky, J., \& Marschner, B. (2016). The use of treated wastewater for irrigation as a component of integrated water resources management: reducing environmental implications on soil and groundwater by evaluating site-specific soil sensitivities. In Integrated Water Resources Management: Concept, Research and Implementation (pp. 459-470). Springer, Cham.

Shachaf Environmental Planning (2014). The national survey of the composition of waste, final report for the MoEP (in Hebrew). Available at: http://www.sviva.gov.il/InfoServices/Reservoirlnfo/DocLib2/Publications/P0701-P0800/P0749.pdf $\quad$ (accessed 22.8.18)

Tous, J., \& Ferguson, L. (1996). Mediterranean fruits. Progress in new crops, $416-430$

WFD. (2008). Directive 2008/98/EC of the European Parliament and for the Council of 19 November 2008 on waste and repealing certain Directives. Official Journal L312, 22/11/2008, P. 0003-0030.

WR. (2004). Water Regulations (Use and Disposal of Sludge) 57642004. Available at: http://www.sviva.gov.il/English/Legislation/ Documents/Water\%20Laws\%20and\%20Regulations/WaterRegulations-UseAndDisposalOfSludge-2004.pdf (accessed 22.8.18). 